\title{
ON THE EFFECT OF ALKALI TREATMENT AT HIGH TEMPERATURE FOR PULP QUALITY
}

\author{
by Yasusuke Shinomiya
}

(Received 1 St, Nov. 1941)

With the object of improving the quality of pulp by alkali treatment at high temperature, the following researches are published in this paper and submitted for reference.

Now, pulp refining at high temperature inserted for the midlle process at the multistage of the bleaching process, and in the first place, it is most important to give a suitable treatment to the unbleached pulp.

That fact has to do with pre-bleaching for unbleached pulp.

At the first stage in the multistage bleaching process chlorine is used very efficiently, but Ligno chlorinic Salts which remain in the pulp after washing will be rejected by alkali refining at high temperature with hemi-cellulose, and this process is perfected by using after-bleaching a little oxidising agent.

Comparison of refined degree of pulp.

\begin{tabular}{|c|c|c|c|c|c|c|}
\hline $\begin{array}{l}\text { addition of } \\
\text { alkali at high } \\
\text { temp. } \\
\text { treatment. }\end{array}$ & $\begin{array}{c}\alpha \text {-Cellnlose in } \\
\text { unblonchea } \\
\text { bulp }\end{array}$ & $\begin{array}{l}\alpha \text {-Cellulose in } \\
\text { refined pulp. }\end{array}$ & $\begin{array}{l}\text { refined degree } \\
\text { of } \alpha \text {-Cellnose } \\
\text { at refining. }\end{array}$ & $\begin{array}{c}\text { viscosity in } \\
\text { moleached } \\
\text { pulp. }\end{array}$ & $\begin{array}{l}\text { viscosity in } \\
\text { refineal pulp. }\end{array}$ & $\begin{array}{l}\text { reference of } \\
\text { viscosity. }\end{array}$ \\
\hline $8 \%$ & $88.46 \%$ & $93.86 \%$ & +5.408 & 35.2 & 26.2 & -9 \\
\hline $6 \%$ & 88.47 & 92.23 & +3.76 & 39 & 23.01 & -15.99 \\
\hline $5 \%$ & 88.21 & 92.17 & +3.96 & 28.63 & 18.2 & -10.43 \\
\hline $4 \%$ & 87.95 & 91.29 & +3.34 & 29.08 & 16.95 & -12.13 \\
\hline $3 \%$ & 88.46 & 90.84 & +2.38 & 24.23 & 18.26 & -5.97 \\
\hline $2 \%$ & 88.20 & 90.36 & +2.18 & 24.88 & 21.54 & -3.34 \\
\hline
\end{tabular}

The conclusion drawn from the results obtained is as follows.

After first doing extreme chlorination at a low temperature, refining at a high temperature is done by adding alkali in various concentrations, and when the liquor is in the bleacher it is buffered by again adding an alkali solution afterbleaching I have found that the degree of refine. ment of the refined pulp heightened by adding alkali the larger the quantity the better.

Details are as follows:

In the case of unbleached pulp of the following composition.

$\begin{array}{lc}\alpha \text {-cellulose } & 87 \% \\ \text { viscosity } & 35 \\ \text { bleacheability } & 9 \sim 11 \% \\ \text { hardness } & 70 \mathrm{sec} .\end{array}$


(12)

Alkali treatment. (in chlorination at low temperature)

$\begin{array}{lr}\text { concentration of pulp in bleather } & 5 \% \\ \text { quantity of alkali added } & 2 \sim 8 \% \\ \text { temperature } & 85 \sim 97^{\circ} \mathrm{C} \\ \text { hours of treatment } & 3 \sim 4 \mathrm{hr} \text {. } \\ \text { after-bleacking } & 5 \% \\ \text { concentration of pulp } & \\ \text { quantity of alkali added } & 0.5 \sim 1.0 \% \\ \text { temperature } & 40^{\circ} \mathrm{C}\end{array}$

By the above details the results as indicated in the above fig. are obtained and better than the standard degree of whiteness is obtained.

\title{
POMILIO CONTINUOUS ALKALI-CHLORINE PROCESS
}

\author{
by E. SALVATORE ${ }^{+}$
}

(Received 1st, Nop., 1941)

The analytical method of Cross and Bevan (1) for extracting cellulose from plants already at an early date indicated the possibility of using soda and chlorine on an industrial scale for pulp making in a more efficient way than by the methods hitherto used. However, varions difficulties were encountered when trying to apply laboratory results to industry, and it took a long time before suitable methods and apparatus could be developed.

U. Pomilio and his collaborators ultimately succeeded in designing a working method whereby the alkali and chlorine could be used in a continuous system. This method has been adopted at several plants all around the world with excellent results, both as regards the production costs and the quality of the product.

The rapid development of the Pomilio system is due to the fact that, in the same way as in the analytic methods of Cross and Bevan, the breaking up of the vegetable tissue is done in several consecutive phases by means of extremely diluted reagents. The progressive elimination of all the undesired compounds of the raw material is thus attained without injuring the cellulose molecule, and the final product will therefore be constituted of loose and perfectly sound fibres which can be easily bleached.

Moreover, considering that these working phases run continuously and steadily without the

\footnotetext{
+ Gadelius \& Co., Ltd., Tokyo.
} 